\title{
Stem Cells and Liver Regeneration
}

\author{
ANDREW W. DUNCAN ${ }^{*}$, CRAIG DORRELL ${ }^{*}$, and MARKUS GROMPE ${ }^{*}, \ddagger$
}

\author{
* Oregon Stem Cell Center, Oregon Health \& Science University, Portland ₹ Papé Family \\ Research Institute, Department of Pediatrics, Oregon Health \& Science University, Portland, \\ Oregon
}

\begin{abstract}
One of the defining features of the liver is the capacity to maintain a constant size despite injury. Although the precise molecular signals involved in the maintenance of liver size are not completely known, it is clear that the liver delicately balances regeneration with overgrowth. Mammals, for example, can survive surgical removal of up to $75 \%$ of the total liver mass. Within 1 week after liver resection, the total number of liver cells is restored. Moreover, liver overgrowth can be induced by a variety of signals, including hepatocyte growth factor or peroxisome proliferators; the liver quickly returns to its normal size when the proliferative signal is removed. The extent to which liver stem cells mediate liver regeneration has been hotly debated. One of the primary reasons for this controversy is the use of multiple definitions for the hepatic stem cell. Definitions for the liver stem cell include the following: (1) cells responsible for normal tissue turnover, (2) cells that give rise to regeneration after partial hepatectomy, (3) cells responsible for progenitor-dependent regeneration, (4) cells that produce hepatocyte and bile duct epithelial phenotypes in vitro, and (5) transplantable liver-repopulating cells. This review will consider liver stem cells in the context of each definition.
\end{abstract}

The adult mammalian liver is composed of diverse cell types that arise from various embryologic origins. In this review, the discussion of the "liver stem cell" or "hepatic stem cell" focuses on precursors of 2 liver epithelial cell types: hepatocytes and bile duct epithelial cells.

\section{Organization and Functions of Adult Mammalian Liver}

An appreciation of liver architecture is essential to the understanding of hepatic stem cell biology. An extensive description of liver organization/function is found elsewhere. ${ }^{1}$ Briefly, the primary functional unit of the liver is the hepatic lobule (Figure $1 A$ and $B$ ). ${ }^{2}$ Located along the lobule perimeter, the portal triad consists of a small portal vein, hepatic artery, and bile duct. Blood enters the liver from the portal vein and hepatic artery, and it flows through liver sinusoids toward the central vein. Rows of hepatocytes form a hepatic plate. The basolateral hepatocyte surface is lined with fenestrated endothelium, unique among capillary beds, forming sinusoidal vessels. These vessels facilitate interactions between blood and the hepatocyte cell surface. ${ }^{3}$ The apical face of adjacent hepatocytes

\section{(C) 2009 by the AGA Institute}

Reprint requests Address requests for reprints to: Markus Grompe, MD, Papé Family Pediatric Research Institute, Oregon Stem Cell Center, Department of Pediatrics, Oregon Health and Science University, 3181 Southwest Sam Jackson Park Road, Mail Code L321, Portland, Oregon 97239-3098. grompem@ohsu.edu; fax: (503) 418-5044. .

Conflicts of interest The authors disclose the following: Dr Grompe holds equity in Yecuris Inc. This company specializes in humanization of mouse livers. The remaining authors disclose no conflicts. 
forms a bile canaliculus. Bile is secreted by hepatocytes into the bile canaliculus and then drains toward bile ducts, which are lined by duct epithelial cells. Bile canaliculi connect with bile ducts via the Canal of Hering, which is also believed to be a niche for liver progenitor cells (see following text).

The liver is responsible for the synthesis of serum proteins; intermediary metabolism of amino acids, lipids, and carbohydrates; and detoxification of xenobiotic compounds. These functions are performed primarily by hepatocytes. Hepatocyte function (eg, gene expression profile and biochemical activities), however, is not identical among all hepatocytes. Rather, hepatocytes perform different roles depending on their physical location within the hepatic lobule. "Metabolic zonation" refers to the differential properties of periportal (adjacent to the portal triad) and pericentral (adjacent to the central vein) hepatocytes. ${ }^{4}$ Periportal hepatocytes, for example, express urea cycle enzymes and convert ammonia to urea. ${ }^{5,6} \mathrm{In}$ contrast, pericentral hepatocytes express glutamine synthase and utilize ammonia to generate glutamine. ${ }^{5}$

\section{Cells Responsible for Normal Liver Tissue Turnover}

Hepatocyte replacement occurs relatively slowly; the average life span of adult hepatocytes ranges from 200 to 300 days. $^{7}$ A number of different hypotheses have been proposed to explain hepatocyte turnover. In one of the earliest models, called "streaming liver," normal liver turnover was proposed to be similar to intestinal regeneration, with young hepatocytes originating in the portal zone and then migrating toward the central vein. ${ }^{8}$ Differential gene expression by periportal and pericentral hepatocytes was believed to arise during the hepatocyte maturation process, which represented a typical lineage progression. Very recent data from Fellous et al support the streaming liver hypothesis in human tissue. ${ }^{9}$ Clonal patches of hepatocytes harboring mitochondrial mutations were found to originate in periportal areas and extend into pericentral regions, suggesting a pattern of hepatocyte differentiation/movement.

However, strong evidence against the streaming liver hypothesis also exists. First, retroviral marking studies provide clear evidence against any hepatocyte migration during normal turnover. ${ }^{10}$ Analysis of the $\mathrm{X}$-inactivation pattern in livers from female mice also argues against hepatocyte migration within the lobule. ${ }^{11}$ Secondly, the gene expression pattern in hepatocytes is dependent on the direction of blood flow. ${ }^{12}$ If blood flow is reversed so that portal blood enters the lobule through the central vein and exits via the portal vein, the gene expression profile is inverted. Lobular zonation, therefore, could be explained by metabolite-induced gene regulation and not lineage progression. Although the contribution of stem cells to normal liver turnover in adult animals is debated, current evidence suggests that most liver maintenance is achieved directly by cell division of hepatocytes and bile duct epithelial cells. ${ }^{13}$

\section{Cells That Give Rise to Regeneration After Partial Hepatectomy}

Partial hepatectomy is a surgical procedure in which specific liver lobes are removed intact without damage to the lobes left behind. The process has been extensively studied and is the subject of several excellent reviews. ${ }^{14-16}$ The excised liver lobes never grow back, but the remaining lobes grow to compensate for the mass of the resected tissue. Reconstitution of the entire liver mass, which is complete within 5-7 days in rodents, is mediated by mature cell types (ie, without stem cells). Classic thymidine labeling studies showed that virtually all rodent hepatocytes in the remaining liver divided once or twice to restore the original cell number within 3-4 days. ${ }^{17,18}$ The earliest labeled hepatocytes are seen 24 hours after partial hepatectomy; the peak of thymidine incorporation occurs after 24-48 hours. Following 
hepatocyte division, the other hepatic cell types also undergo a wave of mitosis, thereby restoring the original number of all liver cells within 1 week.

The regenerative response after partial hepatectomy is mediated by a number of factors. The most important signals are hepatocyte growth factor, ${ }^{19}$ interleukin-6, tumor necrosis factor $\alpha$, transforming growth factor $\alpha$, and epidermal growth factor. Nonpeptide hormones, including triiodothyronine ${ }^{20}$ and norepinephrine, ${ }^{21}$ can stimulate hepatocyte replication in vivo. Much less is known about how liver regeneration is terminated once the appropriate liver mass is restored. Although the exogenous factors (endocrine, paracrine, or autocrine) that sense overall liver size are not known, several intracellular signals have been identified. For example, some evidence suggests that transforming growth factor $\beta 1$ is important in termination of liver regeneration. ${ }^{22}$ Recent work strongly implicates the detection of blood bile acid levels by nuclear receptors, including FXR, as a regulator of liver growth. ${ }^{23}$ In addition, mammalian genes comparable to those in the Drosophila Hippo kinase signaling cascade, which regulates wing mass during development, can also control hepatocyte proliferation. ${ }^{24}$ When YAP, the mammalian counterpart to Yorki, the last gene in the Drosophila Hippo kinase cascade, is overexpressed in a transgenic mouse model, hepatocyte proliferation becomes unchecked and there is massive liver hyperplasia and hepatic carcinogenesis. When YAP hyperexpression is turned off or blocked, liver size returns to normal. It is therefore possible that the Hippo kinase pathway has a decisive role in determining overall liver size. Whether any of these intracellular signals are also important for progenitor-dependent liver regeneration or engraftment is unknown.

\section{Progenitor Cells}

\section{The Identity and Function of Oval Cells}

The capacity of mature liver cells to proliferate in response to common forms of injury is remarkable. However, when this response is impaired, as in the case of a hepatocyteselective proliferative defect, the contribution of hepatic progenitors becomes apparent. A population of small portal zone cells with a high nuclear/cytoplasmic ratio and an ovoid nucleus, first observed in rat liver, has become known as "oval cells." 25 These cells proliferate extensively and, upon migration into the lobule, differentiate into hepatocytes. Although the term "oval cell" is widely used to describe hepatic progenitors, it is important to note that researchers do not agree on the phenotypic and/or molecular traits of these cells. The term "oval cell" is used for a heterogeneous population of liver cells; multiple cell types, including progenitors, mature duct cells, activated stellate cells, and fibroblasts, emerge in livers undergoing oval cell activation, and it is unclear whether oval cells that arise in different species or as a result of different insults are truly comparable. In human pathology, liver progenitors observed in chronic conditions of impaired hepatocyte proliferation or differentiation have been described as intermediate hepatobiliary cells. Such cells bear a strong resemblance to their more extensively studied rodent counterparts.

However, we support the general use of "oval cell response" to describe the activation of liver progenitors in all species. In this review, the terms "oval cell response" or "oval cell activation" will be used to describe to the heterogeneous cellular changes that accompany the appearance of progenitors, whereas "oval cell" will refer to the progenitor(s) itself/ themselves. Cellular markers that will help to identify these various cell types and their relationships are becoming available, ${ }^{26}$ and it seems likely that future descriptions of hepatic cell populations will include surface marker designations.

Regardless of the final nomenclature, the precursors to oval cells are not mature hepatocytes. ${ }^{27}$ The most likely origin of the precursors of oval cells in adult tissue is the Canal of Hering (Figure 1A). Oval cells could be a bipotential transient amplifying cell type $^{28,29}$ derived from normally quiescent true stem cells that reside in the biliary tree. 
Figure $2 A$ depicts the classic view of the lineage relationships during liver progenitor activation and shows only one type of bipotential hepatic oval cell. In contrast, Figure $2 B$ shows a hypothetical liver stem cell hierarchy in which multiple classes of oval cell progenitors exist. A third model, in which there is no bipotential progenitor but distinct precursors for hepatocytes and bile ducts, is also conceivable (Figure $2 C$ ).

Table 1 lists conditions that result in oval cell activation in rodents. Chronic liver injury induced by chemicals such as pL-ethionine or galactosamine exemplify this type of liver damage (Table 1). Administration of toxic drugs is often combined with partial hepatectomy. Many of the compounds that induce oval cell proliferation are DNA-damaging agents or carcinogens; thus, oval cells can be considered precancerous. Rodent oval cell activation is often accompanied by steatohepatitis, in which the hepatocytes become filled with fat vesicles. ${ }^{30-32}$ Alcoholic fatty liver disease, the comparable human condition, has been associated with progenitor cell activation.

In the rat, oval cells coexpress markers of bile duct epithelium (CK19) and hepatocytes (albumin). Furthermore, they express high levels of $\alpha$-fetoprotein (AFP) and thus resemble fetal hepatoblasts in their gene expression profile. ${ }^{25}$ Classically, oval cells have therefore been considered to be bipotential precursors (capable of producing both hepatocytes and bile ducts) to mature epithelial liver cells. However, most of the experimental evidence for oval cell bipotentiality has come from in vitro differentiation of immortal liver cell lines after the oval cell activation. ${ }^{33,34}$ Recently, in vivo genetic lineage tracing studies of the marker Foxl1 have provided evidence for a bipotential precursor during oval cell activation. ${ }^{35}$ Periportal Foxl1-marked cells yielded both hepatocytes and cholangiocytes, although the study did not conclusively address whether a single cell could give rise to both cell types. This and other recent studies have used protocols designed to produce a murine oval cell response analogous to that of the rat. A diet containing 3,5-diethoxycarbonyl-1,4dihydrocollidine (DDC) is particularly effective in this regard, generating ductal proliferation and tissue alterations similar to the rat oval cell response. ${ }^{36}$ Mouse oval cells differ from their rat and human counterparts by not expressing AFP or the rat oval cell marker OV6. Until recently, only one oval cell-specific antibody, termed A6, was available to label mouse oval cells. ${ }^{37} \mathrm{~A}$ panel of antibodies raised against cells present in the mouse oval cell response has shown extensive antigenic heterogeneity among hepatic cells activated by DDC. At least 2 distinct classes of proliferating cells, distinguished by antigen expression and ductal versus periductal localization, are identifiable. ${ }^{26}$ Rat oval cells can be isolated based on surface levels of OV1; there are subpopulations with distinct biological behaviors. ${ }^{38}$ All of these findings emphasize the heterogeneity of oval cell populations. Future studies are expected to reveal the biological roles of the distinct oval cell classes.

Rat oval cells induced by carcinogen exposure have been observed to express genes that are typically associated with hematopoietic stem cells (HSCs) such as stem cell factor and its receptor, c-kit. During the early stages after partial hepatectomy in the 2-

acetylaminofluorene/partial hepatectomy model for oval cell activation, c-kit expression is observed in AFP-positive oval cells, but stem cell factor is expressed in both oval and stellate cells. ${ }^{39}$ Whereas older studies have claimed that the hematopoietic marker Thy- 1 is also highly expressed on rat oval cells, ${ }^{40,41}$ recent work has shown that it in fact marks myofibroblasts instead. ${ }^{42}$ The expression of hematopoietic progenitor markers in oval cells is not unique to the rat. Human liver oval cells can express CD34 as well as the bile duct marker CK19. ${ }^{43}$ In addition, nonhematopoietic cells that are c-kit positive have been identified in human pediatric liver disease. Finally, very high levels of mouse hematopoietic progenitor marker Sca-1 have been reported to be expressed on DDC-activated mouse oval cells. ${ }^{44}$ Therefore, multiple independent studies support the concept that hepatic oval cells, but not regenerating hepatocytes, can express genes also found in HSCs. These findings 
have contributed to the hypothesis that oval cell precursors might be found in the bone marrow.

\section{Molecular Regulation of the Oval Cell Response}

The oval cell response can be divided into 4 phases: activation, proliferation, migration, and differentiation. ${ }^{45}$ Genetic studies in the mouse and in vitro studies of oval cell lines in culture have identified some factors involved in oval cell activation, and these are summarized in Figure 3. Multiple epithelial, hematopoietic, and mesenchymal cell types are present during hepatic progenitor activation, and in many cases it is unclear which cells transmit and which receive important molecular signals. Factors that impact the oval cell response can do so either directly (acting on the proliferating epithelial cells) or indirectly by signaling to a non-epithelial cell type, which might, in turn, then act on the oval cells or their progenitors. In addition to describing cellular topology, future studies must examine the temporal sequence of signaling events.

Several lines of evidence demonstrate the importance of interferon gamma in oval cell activation. Interferon gamma-deficient mice have an attenuated oval cell response but increased liver regeneration after partial hepatectomy. ${ }^{46,47}$ Conversely, the addition of interferon gamma and tumor necrosis factor to lipopolysaccharide (both growth factors are present during liver growth) arrests the proliferation of cultured hepatocytes but promotes oval cell activation. ${ }^{48}$ Transforming growth factor $\beta$ has also been reported to induce differential regulation of mature hepatocytes and immature oval cells. Transforming growth factor $\beta$ induces apoptosis in mature hepatocytes but does not affect oval cells or bile duct epithelium. ${ }^{30}$ Thus, one of the emerging themes of hepatic progenitor activation is that inflammatory cytokines have opposite effects on hepatocytes and progenitors.

Interleukin-6 appears to regulate activation and proliferation of oval cells. Mice that lack interleukin-6 have reduced progenitor activation in response to a cholinedeficient diet. ${ }^{49}$ The absence of tumor necrosis factor $\alpha$ has also been shown to impair oval cell activation, ${ }^{50}$ although tumor necrosis factor receptor 2 knockout mice have a normal oval cell response.

One pathway has been associated with the emergence of oval cells even in the absence of injury. Transgenic mice that express the tumor necrosis factor-like weak inducer of apoptosis (TWEAK) in hepatocytes display an oval cell response and the emergent proliferating ducts express the TWEAK receptor Fn $14 .{ }^{51}$ TWEAK-Fn14 signaling appears to be progenitor specific in the liver; Fn14 is absent on hepatocytes, and hepatocyte proliferation occurs at normal levels despite TWEAK expression.

Recent studies have indicated an important role for hedgehog signaling in progenitor activation, particularly in alcoholic fatty liver disease. In mice and humans, alcoholic steatohepatitis induces proliferation of immature duct cells in the portal tracts. ${ }^{30,52}$ This is accompanied by transcriptional up-regulation of hedgehog family members (Sonic hedgehog and Indian hedgehog) and expression of hedgehog target genes in the proliferating ducts as well as the adjacent myofibroblasts. ${ }^{30}$ Hedgehog inhibitors can impair progenitor proliferation. ${ }^{52}$ Indirect evidence suggests that activation of hedgehog signaling might be downstream of transforming growth factor $\beta$ (ie, the inflammatory response).

\section{Oval Cells as Liver Cancer Stem Cells}

The observation that many reagents that activate oval cells in rodents are carcinogenic supports the idea that alterations in the frequency or proliferative capacity of oval cells can contribute to liver cancer. In mice and rats, some hepatocellular carcinomas and cholangiocarcinomas have been proposed to be of oval cell origin. ${ }^{53,54}$ The detection of cmyc, Ras, and AFP after oval cell activation is consistent with this hypothesis. ${ }^{55,56} \mathrm{In}$ 
humans, oval cells/intermediate hepatobiliary cells have also been observed in samples from patients with liver cancer or chronic diseases. ${ }^{57}$ Hepatocellular carcinomas sometimes express markers of the duct lineage, such as CK7 and CK19, despite a predominantly hepatocytic phenotype. ${ }^{58}$ Cholangiocarcinomas, conversely, have been observed to yield intermediate hepatocytes. ${ }^{59}$ These tumors often incorporate oval cell activation in the form of a ductular reaction. Thus, progenitor cells might have a role in the emergence and maintenance of some liver tumors. Elucidating the molecular processes of oval cell activation may lead to important cancer therapeutics.

\section{Cells With In Vitro Hepatocyte and Bile Duct Epithelial Differentiation Potential}

In vitro culture models for hepatic stem cell growth and differentiation have been developed to study the potential of different cell populations and to produce clinically transplantable material. Cell surface labels are used to sort cells and directly isolate putative liver stem cells for culture and determination of growth and differentiation potential. Alternatively, immortal cell lines derived from liver tissue by extensive in vitro manipulation and growth have been used to study hepatic growth and differentiation. Recently, much effort has been devoted to the targeted differentiation of pluripotent embryonic stem cells toward the hepatocytic lineage. Finally, several investigators have devised strategies to conditionally immortalize differentiated hepatocytes for in vitro expansion and subsequent transplantation. ${ }^{60}$

Liver cell lines have been developed from several mammalian species, including mouse, rat, pig, and human, in the hope of generating therapeutically useful numbers of transplantable cells. The only cell lines with documented therapeutic effects in animal models are those lines or primary cultures that were originally derived from primary hepatocytes (eg, Kobayashi et al, ${ }^{61,62}$ Gupta and Chowdhury, ${ }^{63}$ and Fox et al ${ }^{64}$ ). However, studies of primary progenitors are of increasing importance as culture methodology and cell isolation capabilities improve.

\section{Prospective Isolation of Hepatocyte Progenitors by Cell Sorting}

Cell purification techniques that utilize magnetic selection and fluorescence-activated cell sorting are widely used to isolate viable cells, even from solid tissues such as liver. However, the successful isolation of putative progenitors from the liver requires an assay of progenitor function. Several laboratories have reported colony-forming assays for mouse and human hepatic epithelial cells. ${ }^{65-67}$ The colonies can in some cases be grown in fully defined conditions, facilitating studies of the effects of individual factors. Epithelial colonyforming cells (ECFCs) were fractionated from fetal mouse liver by fluorescence-activated cell sorting and analyzed for their proliferative and differentiation capacities. ${ }^{65} \mathrm{~A}$

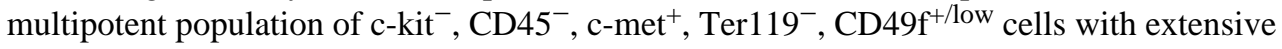
proliferative capacity was identified in embryonic day 13.5 in mouse liver. In addition to their in vitro hepatocytic and biliary differentiation capacities, these cells could express multiple pancreatic markers after long-term culture or transplantation to an in vivo pancreatic environment. Similar sorting approaches were used to isolate cells that express

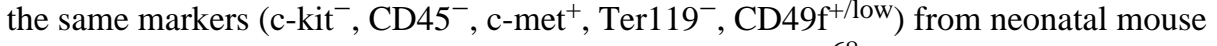
pancreas; these were found to produce hepatocytes in vitro. ${ }^{68}$ Adult liver cells, however, did not yield colonies under the conditions used for fetal or neonatal cells. New growth conditions were recently described in which adult mouse liver cells could generate both large mixed-lineage and small unilineage colonies. ${ }^{66}$ The large mixed-lineage colonies were extensively expanded and shown to produce functional hepatocytes in vivo. Adult ECFCs express the surface marker CD133 and lack the hematopoietic markers CD45 and Ter119. 
Approximately $1 \%$ of $\mathrm{CD} 133^{+} \mathrm{CD} 45^{-} \mathrm{Ter} 119^{-}$cells from a DDC-treated liver are colony forming, whereas cells with a similar surface phenotype isolated from normal liver formed only small colonies. ${ }^{66}$

ECFCs have also been found in human liver specimens; cells that express both EpCAM and CD133 are capable of forming colonies. Once again, 2 distinct colony morphologies were observed. The large-type colonies could be repeatedly passed and expanded, suggesting that they possessed self-renewal capacity. In vivo hepatocytic differentiation was observed after transplantation of very large numbers of in vitro expanded ECFCs. It remains unclear whether freshly isolated cells would have been transplantable or if prior growth in culture is required. Importantly, at most, $0.1 \%$ EpCAM-positive cells formed colonies, indicating that only a small subfraction actually have progenitor activity. Most bile duct epithelial cells are positive for these markers, and it is unlikely that all of them are progenitors. ${ }^{69}$ Data from studies in mouse and human systems indicate that the hepatic progenitors are a subset of the ductal cell population. Therefore, it is currently not possible to detect human or rodent hepatic stem cells using simple histochemical markers. It is also unclear whether the ECFCs represent the actual hepatic stem cell residents in vivo.

\section{Extrahepatic Liver Cell Progenitors}

Multipotent stem/progenitor-like cells have been isolated from tissues outside the liver, and in some cases hepatocytic differentiation has been reported. These cells are unlikely to serve as liver stem cells within the organism but nonetheless are of therapeutic and biomedical interest. In most of these systems, only in vitro differentiation into cells that resemble hepatocytes has been achieved, whereas in vivo assays indicate that the cells generated thus far are only "hepatocyte-like" and not yet fully functional.

\section{Multipotent adult progenitor cells and mesenchymal stem cells as hepatocyte progenitors-Multipotent adult progenitor cells ${ }^{70-72}$ are a unique population of progenitors from multiple mammalian species that are generated in long-term culture by plating nonhematopoietic adherent cells from the bone marrow. They are telomerase positive and grow stably in culture for many passages if kept at low density. These cells have been reported to have properties similar to embryonic stem cells in that they can be differentiated toward multiple lineages in vitro under the appropriate conditions. ${ }^{73}$ When grown on Matrigel with fibroblast growth factor 4 and hepatocyte growth factor, multipotent adult progenitor cells generate hepatocyte-like cells that synthesize urea, secrete albumin, and induce cytochrome $\mathrm{p} 450$ in response to phenobarbital. ${ }^{72}$}

Like multipotent adult progenitor cells, mesenchymal stem cells (MSCs) usually originate in the bone marrow and can be isolated by expanding the fraction that strongly attach to plastic tissue culture dishes. They are clearly multipotent, giving rise to multiple mesenchymal lineages, and numerous reports indicate that they can also differentiate into hepatocyte-like cells in vitro. ${ }^{74-76}$ The differentiation protocols sometimes involve exposure of MSCs to a demethylating drug such as 5-azocytidine followed by medium that contains typical hepatocytic differentiation factors such as epidermal growth factor and hepatocyte growth factor. ${ }^{75}$ MSCs derived from human fat have also been induced to develop into a hepatocyte-like state, characterized by albumin and glycogen production as well as the ability to detoxify ammonia. This differentiation was induced in culture using multiple factors such as dexamethasone, epidermal growth factor, hepatocyte growth factor, fibroblast growth factor 1, fibroblast growth factor 4, and oncostatin M. ${ }^{76}$ Although MSCderived hepatocyte-like cells have many characteristics of mature liver cells and can engraft in vivo, the extent of functional liver repopulation has, to date, been modest. 
Amniotic stem cells-Human amniotic fluid and membranes have been used as sources of pluripotent cells, which are capable of differentiating into endoderm. ${ }^{77,78}$ Specific protocols for the induction of the hepatic phenotype have been developed and are similar to the differentiation regimens used for other progenitors. ${ }^{79}$ The hepatocyte-like cells that have been generated using the most optimized regimens express cytochrome p450 and other genes that are typical of hepatocytes.

\section{Pluripotent stem cells (embryonic stem cells and induced pluripotent stem} cells)-The prospect of using pluripotent embryonic stem cells as a source of all types of differentiated cells, including the hepatic lineage, has gained considerable attention. Mouse and human embryonic stem cells (ESCs) can be induced to differentiate toward the endodermal and hepatocytic lineages in vitro by sequential administration of specific growth factors (reviewed in Asahina et $\mathrm{al}^{80}$ ). According to the prevailing paradigm, natural embryonic development should be mimicked to obtain the most functional mature cells. Therefore, the first step of many protocols typically involves the generation of embryoid bodies, followed by the induction of definitive endoderm using activin $\mathrm{A} .{ }^{81}$ The endoderm cell population can then be further induced toward the hepatic lineage by exposure to BMP-4 and fibroblast growth factor $2 .{ }^{81}$ Cells produced in this fashion express typical markers such as albumin, but usually also express AFP, which is absent from normal adult hepatocytes. Transplantation of these cells to the liver results in engraftment with both mature hepatocytes ${ }^{81,82}$ and bile duct epithelial cells. ${ }^{82}$ The level of liver repopulation obtained with hepatocyte-differentiated ESCs is very low but increases somewhat when the cells are transplanted into MUP-urokinase plasminogen activator/severe combined immunodeficient (SCID) mice. ${ }^{82}$ To date, most published ESC differentiation protocols generate hepatocyte-like cells, but not the fully functional, mature, and transplantable equivalents of hepatocytes that are isolated from adult liver. New in vitro culture protocols, using factors such as Wnt $3 \mathrm{a},{ }^{83}$ continue to offer improvements in the hepatocyte function of differentiated cells. Furthermore, it has been reported that by selecting for cells expressing markers such as the asialoglycoprotein receptor, it is possible to isolate the most hepatocytelike cells in the culture. ${ }^{84}$ It appears likely that conditions and protocols will be developed for the practical production of ESC-derived hepatocytes. For therapeutic utility, however, such cells should be immune matched to obviate the need for suppressive drugs. The development of ESC-like induced pluripotent stem (iPS) cells from adult somatic tissue ${ }^{85}$ may prove useful in this regard. Although it is unlikely that the routine derivation of patientspecific iPS cells will be cost effective, a library of iPS lines covering common major histocompatibility complex alleles might permit the production of sufficiently immunematched hepatocytes. Confirmation that iPS cells have hepatocyte-lineage differentiation capacity comparable to that of ESCs is needed, and even if this is the case, similar limitations (eg, the potential for teratoma formation) will remain. Nevertheless, iPS-derived hepatocytes are a very promising population for future therapeutic transplantation.

\section{Cell Lines With Liver Repair Capacity}

Transformed cell lines have limited utility as clinically transplantable agents. Experimental studies of such lines, however, have provided valuable insights into the potential of progenitor and differentiated liver cells.

Rodent cell lines-In studies of rat liver regeneration, the WB-344 cell line has proven to be a useful model. ${ }^{86-89}$ These cells exhibit several properties of an oval cell-like hepatic progenitor, can be propagated in an undifferentiated state, and have the impressive capacity to produce functional hepatocytes when intrahepatically transplanted to recipient rats. In the mouse, the derivation of useful hepatic epithelial lines has been facilitated by the use of transgenic animals. Cultures of liver cells from animals that constitutively overexpress c- 
met $^{33,90}$ yielded cell lines with either unipotential (hepatocytic) or bipotential (hepatocytic/ ductal) differentiation capacity. The use of embryonic tissue instead of adult transgenic liver has also been fruitful; bipotential murine embryonic line cells can generate hepatocytes and bile ducts in vitro and in vivo. ${ }^{34} \mathrm{HBC}-3$ cells, ${ }^{91,92}$ which have similar potential, have recently been used to investigate hepatic differentiation fate decisions. ${ }^{93}$

Nonrodent cell lines-Human AKN-1 cells have been reported to possess liver progenitor-like characteristics. ${ }^{94}$ The porcine epiblast-derived line PICM-19 has differentiation capacities similar to those of bipotential murine embryonic line cells but is derived from an even earlier (prepremordium) differentiation stage. ${ }^{95}$

Pancreatic cell lines-The common developmental origin of the adult liver and pancreas has inspired investigation of the potential for pancreas-derived cells in liver repair. ${ }^{96}$ In one study, permanent cell lines with epithelial characteristics were established from liver and pancreas under similar culture conditions. ${ }^{97}$ Extensive phenotypic characterization was performed and, under the conditions of analysis, none of the cell lines expressed differentiated markers of either pancreas or liver. However, their morphologic characteristics and expression profiles (eg, aldolase, lactate dehydrogenase, and cytokeratins) were indistinguishable, suggesting that primitive epithelial cells from both organs are similar. ${ }^{97}$

Others established permanent "duct" rat epithelial cell lines that express cytokeratins 8 and 19 and carbonic anhydrase. ${ }^{98}$ When these cells were implanted into a collagen matrix in rats, either subcutaneously or into the peritoneal cavity, several hepatocyte-specific markers were expressed and pancreatic duct markers were silenced, most notably the cells transplanted into the mesenteric fat pad. The expression levels of albumin, transferrin, and aldolase B approached those observed in normal adult hepatocytes. Again, these data are consistent with the model of a common endodermal hepatopancreatic stem cell.

\section{Transplantable Liver-Repopulating Cells}

One of the hallmarks of tissue-specific stem cells is their capacity to repopulate a specific organ and restore its function. HSCs, for example, were identified based on their ability to reconstitute blood lineages in lethally irradiated hosts. ${ }^{41}$ Over the past 2 decades, similar assays were developed to identify liver stem cells; a small number of transplanted donor cells were found to engraft in the liver and expand to replace $>50 \%$ of the liver mass. Such models allow for the replacement of only hepatocytes by transplanted cells. Efficient repopulation of the biliary system has not been reported, but it is possible to functionally evaluate hepatic stem cell populations based on their capacity for liver repopulation.

Animal models used for repopulation studies are summarized in Table 2. Each model shares a common theme: transplanted cells have a strong selective advantage over endogenous host hepatocytes. In many models, this selection occurs because of genetic differences between the transplanted and endogenous cells (transgene/knockout). Inhibition of endogenous hepatocyte proliferation with DNA-damaging agents, including chemicals and $\gamma$-irradiation, has also been used. Targeted liver irradiation (ie, not total body irradiation) has been shown to be particularly effective in animal models and might eventually be used in a clinical setting. ${ }^{99}$ Recently, it has been shown that mouse liver can be repopulated with human hepatocytes. ${ }^{100-102}$ Immune-deficient mice have been crossed with strains that provide an environment that selects for transplanted cells, such as transgenic mice that express albumin-urokinase plasminogen activator ${ }^{101}$ or are deficient for a liver-specific enzyme, fumarylacetoacetate hydrolase (Fah), involved in tyrosine catabolism. ${ }^{102}$ Some chemical 
exposure regimens can also be used to select for transplanted hepatocytes. ${ }^{103}$ These models will serve as in vivo assays for the development of human hepatocyte progenitors.

In vivo models have been used to determine the identity of transplantable liver-repopulating cells; it was shown that these cells could be serially transplanted for $>100$ cell doublings without loss of functionality. ${ }^{104}$ Interestingly, hepatocytes were the only donor-derived cells that were found to have liver repopulation capacity. No biliary epithelium or other cell types of donor origin were found to have this ability, indicating that the hepatocyte itself might be a "unipotential" stem cell.

\section{Hepatocytes as Liver-Repopulating Cells}

Liver repopulation is unique among organ systems. In contrast to the hematopoietic system, where mature adult blood cells have minimal proliferative capacity, differentiated hepatocytes themselves have high capacity for liver repopulation. First, mature hepatocytes (identified by size fractionation, retroviral marking, or serial transplantation) were transplanted into livers of Fah knockout mice. ${ }^{105}$ Large, binucleated hepatocytes that represented $\sim 70 \%$ of the hepatocyte population were found to mediate most of the liver repopulation. Secondly, fusion-derived hepatocytes, which by definition are at least tetraploid, that were serially transplanted were capable of at least 30 cell divisions without loss of function. ${ }^{106}$ Finally, fluorescence-activated cell sorting-isolated polyploid hepatocytes proliferated extensively after transplantation into livers of urokinase plasminogen activator transgenic mice. ${ }^{107}$ Together, these experiments show that mature, polyploid adult hepatocytes have a high degree of replicative potential. It is important to note that the nature of the human cells that are capable of liver repopulation ${ }^{102}$ has not been definitively determined. However, in human patients with hereditary tyrosinemia, the large size of clonal revertant nodules (ie, healthy liver tissue derived from spontaneous hepatocyte mutations that correct the underlying genetic defect) indicates that mature human hepatocytes also have extensive regenerative potential. ${ }^{108}$

Some studies have indicated that hepatocytes are bipotential. In vitro and in vivo transplantation experiments have shown hepatocyte differentiation into ductular epithelium. ${ }^{109}$ These results are provocative, suggesting that there are no stem cells in the liver at all, but that all regenerative responses, including the oval cell response, rely on hepatocytes. Taken together, the data strongly suggest that fully differentiated hepatocytes, which constitute the majority of liver cells, are efficient in liver repopulation and have stem cell-like capacity for cell division.

\section{Liver Repopulation by Nonhepatocytes}

Although mature hepatocytes are serially transplantable liver-repopulating cells, ${ }^{104,107}$ other cell types can also repopulate the liver. Liver repopulation has been shown to be mediated by nonhepatocyte cell types such as fetal hepatoblasts, oval cells, pancreatic liver progenitors, MSCs, and HSCs. Figure 4 highlights the diversity of cells with liver repopulation potential.

Liver repopulation by fetal hepatoblasts-During embryonic development, the fetal liver bud contains hepatoblasts. These cells express AFP and hepatocyte (albumin) and biliary (CK19) markers and could represent fetal liver stem cells that are capable of regenerating hepatocytes and the biliary system.

Several studies have investigated transplantation of hepatoblasts. ${ }^{10-113}$ One study used fetal rat liver cells to show at least 3 distinct subpopulations of hepatoblasts exist between embryonic days 12 and 14. Based on histochemical markers, one population appeared to be 
bipotential and the other 2 harbored either unipotent hepatocyte or biliary epithelial cell phenotypes. ${ }^{110}$ Transplantation experiments showed that the bipotential cells proliferated in rats that were exposed to retrorsine, whereas the unipotent cells proliferated even in the control rats. In each case, proliferative signals (from partial hepatectomy or thyroid hormone) were required to augment expansion of transplanted populations. ${ }^{110}$ Donorderived hepatocyte cords and mature bile duct structures were detected 1 month after transplantation. The researchers did not determine, however, if both cell lineages were derived from a clonal precursor. Cell sorting experiments have been used to identify the cell surface characteristics of the hepatoblasts that repopulate rodent liver. Liver-repopulating cells in mice, isolated at embryonic day 12.5, were positive for E-cadherin, Dlk-1, and Sca-1 but negative for hematopoietic markers such as c-kit, CD34, and CD45. ${ }^{112}$ Similarly, in the rat, cells positive for Dlk-1 contained repopulating activity. ${ }^{113}$ Human hepatoblasts also harbored liver-repopulating capacity, as seen in xenotransplantation studies, ${ }^{111}$ confirming the results obtained with rodent cells. These results indicate that hepatoblasts could represent a bipotential subpopulation with significant proliferative potential in the fetal liver.

Liver repopulation by oval cells-Cell culture experiments, discussed previously, show that oval cells differentiate into mature epithelial liver cells (ie, hepatocytes and bile ducts). To extend these observations, oval cell differentiation capacity was tested in transplantation experiments. Transplanted oval cells derived from rat liver or pancreas proliferate and differentiate into mature hepatocytes, even under nonselective conditions. ${ }^{114}$ Recent repopulation studies utilizing an in vivo selection model indicated that mouse oval cells (induced by DDC) have extensive liver repopulation capacity. ${ }^{27,66}$ Furthermore, clonal lines of $\mathrm{CD}_{133^{+}}$cells, isolated from livers of mice exposed to DDC, expanded significantly following transplantation and gave rise to hepatocytes. ${ }^{66}$ It remains to be proven whether single oval cells differentiate into mature hepatocytes and bile duct epithelium in transplantation experiments. Nonetheless, oval cells isolated from the adult liver represent a promising source for cell-based therapy.

Liver repopulation by pancreatic progenitors-During embryogenesis, the main pancreatic cell types develop from a common endodermal precursor located in the ventral foregut, including ducts, ductules, acinar cells, and the endocrine $\alpha, \beta$, and $\delta$ cells. ${ }^{115,116}$ Importantly, the main epithelial cells of the liver, hepatocytes, and bile duct epithelium are also believed to arise from the same region of the foregut endoderm. ${ }^{117,118}$ This tight relationship between liver and pancreas during embryonic development has raised the possibility that a common hepatopancreatic precursor/stem cell might persist in adult liver and pancreas.

Hepatocytes or hepatocyte-like cells emerge from the rodent pancreas in response to numerous stimuli, including the carcinogen $\mathrm{N}$-nitroso-bis(2-oxopropyl)amine, ${ }^{119} \mathrm{a}$ peroxisome proliferator $\mathrm{Wy}-14643,{ }^{120}$ copper fasting/refeeding, ${ }^{121}$ and keratinocyte growth factor. ${ }^{122}$ In humans, the existence of pancreatic liver progenitor cells is supported by the expression of hepatocellular markers in pancreatic cancers. ${ }^{123}$ Furthermore, studies in Fahnull mice have shown the existence of hepatocyte progenitors in pancreas of adult mice. ${ }^{124}$ The pancreata of control, adult wild-type mice were digested into single cells and then transplanted into Fah-null mice. Although only $\sim 10 \%$ of these mice survived long-term and had extensive liver repopulation, $>50 \%$ of recipients had donor-derived $\mathrm{FAH}^{+}$hepatocyte nodules. ${ }^{124}$ Based on the number of hepatocyte nodules formed, it was estimated that pancreatic liver precursors were rare $(\sim 0.02 \%)$ in the donor cell population.

In addition to the existence of liver progenitors in the pancreas, there is also evidence for pancreatic precursors in the liver. Subsets of liver tumors, particularly cholangiocarcinomas, expressed pancreatic markers such as pancreatic-type amylase ${ }^{125}$ and lipase. ${ }^{123}$ Similarly, 
liver-derived oval cell lines secreted insulin in culture and, upon transplantation into diabetic rats, restored pancreas function. ${ }^{126}$ Overexpression of transcription factors that are expressed during pancreas development promoted the emergence of insulin-secreting cells in the liver. ${ }^{127,128}$ One explanation for the presence of hepatocyte precursors in the pancreas and pancreatic precursors in the liver is that an adult hepatopancreatic stem cell exists that is similar to the ventral foregut endoderm precursor that exists during embryonic development (Figure 2A). Further studies are required to determine if this model is accurate.

Liver repopulation with MSCs-MSCs have recently been shown to promote liver repair in cases of liver damage. Transplantation of MSCs, isolated from human umbilical cords, ${ }^{129}$ adipose tissue, ${ }^{130}$ bone marrow, ${ }^{131}$ or rat bone marrow, ${ }^{132}$ improved liver function of rodents undergoing acute liver damage (eg, carbon tetrachloride injections). Infusion of hepatocyte-like cells, which were differentiated in vitro from MSCs, also improved liver function following acute injury. ${ }^{131,133}$ Improved liver function was shown by monitoring the level of liver enzymes in the serum, such as aspartate aminotransferase and alanine aminotransferase. The pro-liver effects of MSC therapy are hotly debated. Some reports show failure of MSCs to improve liver function during chronic liver damage (eg, alcoholic liquid diet plus daily carbon tetrachloride). ${ }^{134}$ Furthermore, increasing evidence suggests that MSCs may promote liver cirrhosis. For example, in mouse models for liver cirrhosis, exogenous mouse ${ }^{135}$ and human ${ }^{136}$ MSC populations promoted the emergence of myofibroblasts, which are involved in the fibrotic response. It is unclear whether the benefits of MSC therapy outweigh the potential risks.

Two primary mechanisms could explain the therapeutic effects of MSCs or MSC-derived hepatocytes in liver injury. First, MSCs could generate cells that function as normal hepatocytes. ${ }^{129-133}$ Following engraftment in the liver, which occurs at very low levels, transplanted cells express markers of donor hepatocytes. Differentiation toward the hepatocytic lineage, therefore, must occur in the parenchymal microenvironment (for transplanted MSCs) ${ }^{129-132}$ or in culture (for MSC-derived hepatocyte-like cells). ${ }^{131,133}$ For example, clusters of cells expressing human albumin were detected in livers of carbon tetrachloride-treated NOD-SCID mice transplanted with human bone marrow MSCs and MSC-derived hepatocyte-like cells. ${ }^{131}$ Similar observations were made with human umbilical cord MSCs (AFP expression) ${ }^{129}$ and hepatocyte-like cells from human adipose MSCs (albumin expression). ${ }^{133}$ To date, only low levels of liver repopulation with either MSCs or MSC-derived hepatocyte-like cells have been reported.

The second mechanism by which MSCs could promote liver repair is indirect. Soluble factors secreted by MSCs facilitate liver recovery in response to acute damage. For instance, infusion of human MSC conditioned medium into rats treated with D-galactosamine (ie, acute liver damage) improved liver function after 24 hours. ${ }^{137,138}$ The effect on endogenous rat hepatocytes was striking: a $90 \%$ decrease in apoptotic hepatocytes and a 3-fold increase in the number of proliferating hepatocytes. ${ }^{138}$ Transplantation studies also support the cell autonomous role of MSCs in liver repair. In response to transplanted human MSC populations (eg, bone marrow-derived MSCs, ${ }^{131}$ umbilical cord-derived MSCs, ${ }^{129}$ or hepatocyte-like cells derived from bone marrow ${ }^{131}$ ), endogenous hepatocytes in carbon tetrachloride-treated mice showed improved survival and increased proliferation. MSCs secrete numerous proteins, but it is unclear which factors facilitate liver recovery. ${ }^{84,137}$ Thus, MSC-mediated liver therapy is a highly promising field with many unanswered questions: which populations are most therapeutic (eg, MSCs, MSC-derived hepatocytes, or MSC-secreted factors), and what types of liver injury are amenable to MSC therapy?

Liver repopulation with bone marrow-derived progenitors-Adult bone marrow provides a microenvironment that supports stem and progenitor cells with diverse 
differentiation potentials, including HSCs and MSCs. A number of early studies suggested that the bone marrow was home to liver progenitor cells as well. In rodents, for example, transplantation of bone marrow and whole livers into genetically distinct rats revealed a subset of marrow-derived oval cells. ${ }^{139}$ Bone marrow-derived hepatocytes were also identified in mice transplanted with bone marrow cells. ${ }^{140}$ Similarly, studies of human patients that received bone marrow from sex-mismatched donors revealed the existence of donor-derived liver epithelial cells. ${ }^{141,142}$ Other studies suggested that HSCs specifically have hepatocyte-generating capacity. Transplantation of a limited number of highly purified HSCs into Fah-null mice resulted in the generation of new hepatocytes with donor characteristics. ${ }^{143}$ Recipient mouse livers were highly repopulated by donor cells, resulting in complete correction of the metabolic liver disease hereditary tyrosinemia. Transplantation of human hematopoietic progenitors has also been shown to produce hepatocyte-like cells in xenotransplantation experiments. Human $\mathrm{CD} 34^{+}$cord blood cells were transplanted into irradiated NOD/SCID mice ${ }^{144,145}$; following liver damage, especially via carbon tetrachloride, a small percentage of hepatocytes $(<0.1 \%)$ were found to express human albumin.

Hepatocytes derived from bone marrow cells could be formed by 3 primary mechanisms. First, bone marrow could theoretically harbor specialized endodermal stem cells that are capable of producing hepatocytes and other epithelial cells. These cells would be analogous to the MSC. Secondly, a single stem cell population could give rise to the blood and hepatocyte lineages. Thirdly, in contrast to differentiation, bone marrow-derived hepatocytes could be derived by cell fusion. To distinguish between these possibilities, transplantation experiments with Fah-null mice were performed using genetic markers for donor bone marrow and recipient hepatocytes. ${ }^{106,146}$ The vast majority of bone marrowderived hepatocytes contained genetic information from both the donor and host, indicating that cell fusion had occurred. Similar experiments from a different laboratory independently confirmed that bone marrow-derived hepatocytes arose via cell fusion. ${ }^{147} \mathrm{HSCs}$ are not believed to participate directly in the fusion process. Rather, the majority of fusion events occur between host hepatocytes and donor-derived myelomonocytic cells. ${ }^{148}$ Although cell fusion accounts for the genesis of most bone marrow-derived hepatocytes, the existence of a bone marrow resident stem cell or transdifferentiation-capable HSC cannot be dismissed.

The functional role of bone marrow-derived hepatocytes is not well understood. In a highly selective liver environment, as seen in Fah knockout mice, hepatocytes derived by cell fusion extensively repopulate diseased liver. ${ }^{106,148}$ However, in the absence of selective pressure, bone marrow-derived hepatocytes contribute minimally to the liver $(\leq 0.001 \%$ hepatocytes). ${ }^{149,150}$ Therefore, it is widely believed that hepatocytes derived from the bone marrow play a minor role, if any, in therapeutic liver repopulation (reviewed by Thorgeirsson ${ }^{15}$ ).

\section{Summary and Conclusions}

Although there is no complete consensus on the roles of hepatic stem cells in adult mammals, recent findings support a dual view in which mature differentiated epithelial liver cells and facultative stem cells mediate liver maintenance and growth. Thus, processes such as normal liver turnover, regeneration after injury, or repopulation following transplantation are mediated by either cell type, depending on the precise circumstances. Oval cells are not a homogeneous well-defined cell population but represent a complex mixture of different cell types, all of which are activated during progenitor-dependent regeneration. Within the oval cell pool, there are proliferative cells that are derived from liver resident oval cell precursors. These cells are likely bipotential in that they can produce hepatocytes and bile duct epithelium. Fetal and adult livers contain rare cells such as ECFCs that are capable of 
forming epithelial colonies in culture at the single-cell level. These ECFCs represent candidates for a bona fide liver stem cell, but definitive proof for this hypothesis does not exist. Multiple studies support the concept that liver stem cells reside within the biliary tree and are a subset of ductal cells. Extrahepatic cells also have the potential to become liver epithelium; although their role in liver physiology remains uncertain, they might be developed for use in therapeutic cell transplantation.

\section{Acknowledgments}

Funding Supported by grants from the National Institute of Diabetes and Digestive and Kidney Diseases to M.G. (R01DK51592) and A.W.D. (F32DK076232).

\section{Abbreviations used in this paper}

$\begin{array}{ll}\text { AFP } & \alpha \text {-fetoprotein } \\ \text { DDC } & \text { 3,5-diethoxycarbonyl-1,4-dihydrocollidine } \\ \text { ECFC } & \text { epithelial colony-forming cell } \\ \text { ESC } & \text { embryonic stem cell } \\ \text { HSC } & \text { hematopoietic stem cell } \\ \text { iPS } & \text { induced pluripotent stem cell } \\ \text { MSC } & \text { mesenchymal stem cell } \\ \text { TWEAK } & \text { tumor necrosis factor-like weak inducer of apoptosis }\end{array}$

\section{References}

1. Desmet, VJ. Organizational principles. In: Arias, IM., editor. The liver-biology and pathobiology. Raven; New York, NY: 1994. p. 3-14.

2. Mall FP. A study of the structural unit of the liver. Am J Anat. 1906; 5:227-308.

3. Wisse E. An electron microscopic study of the fenestrated endothelial lining of rat liver sinusoids. $\mathbf{J}$ Ultrastruct Res. 1970; 31:125-150. [PubMed: 5442603]

4. Jungermann K, Kietzmann T. Zonation of parenchymal and non-parenchymal metabolism in liver. Annu Rev Nutr. 1996; 16:179-203. [PubMed: 8839925]

5. Moorman AF, Vermeulen JL, Charles R, et al. Localization of ammonia-metabolizing enzymes in human liver: ontogenesis of heterogeneity. Hepatology. 1989; 9:367-372. [PubMed: 2563984]

6. Haussinger D, Lamers WH, Moorman AF. Hepatocyte heterogeneity in the metabolism of amino acids and ammonia. Enzyme. 1992; 46:72-93. [PubMed: 1289083]

7. Bucher, NLR.; Malt, RA. Little. Brown; Boston, MA: 1971. Regeneration of liver and kidney.

8. Zajicek G, Oren R, Weinreb M Jr. The streaming liver. Liver. 1985; 5:293-300. [PubMed: 4088003]

9. Fellous TG, Islam S, Tadrous PJ, et al. Locating the stem cell niche and tracing hepatocyte lineages in human liver. Hepatology. 2009; 49:1655-1663. [PubMed: 19309719]

10. Bralet MP, Branchereau S, Brechot C, et al. Cell lineage study in the liver using retroviral mediated gene transfer. Evidence against the streaming of hepatocytes in normal liver. Am $\mathrm{J}$ Pathol. 1994; 144:896-905. [PubMed: 8178942]

11. Shiojiri N, Sano M, Inujima S, et al. Quantitative analysis of cell allocation during liver development, using the spf(ash)-heterozygous female mouse. Am J Pathol. 2000; 156:65-75. [PubMed: 10623655]

12. Thurman RG, Kauffman FC. Sublobular compartmentation of pharmacologic events (SCOPE): metabolic fluxes in periportal and pericentral regions of the liver lobule. Hepatology. 1985; 5:144151. [PubMed: 3967857] 
13. Ponder KP. Analysis of liver development, regeneration, and carcinogenesis by genetic marking studies. FASEB J. 1996; 10:673-682. [PubMed: 8635684]

14. Michalopoulos GK, DeFrances MC. Liver regeneration. Science. 1997; 276:60-66. [PubMed: 9082986]

15. Thorgeirsson SS. Hepatic stem cells in liver regeneration. FASEB J. 1996; 10:1249-1256. [PubMed: 8836038]

16. Michalopoulos GK. Liver regeneration. J Cell Physiol. 2007; 213:286-300. [PubMed: 17559071]

17. Bucher NLR, Swaffield MN. The rate of incorporation of labeled thymidine into the deoxyribonucleic acid of regenerating rat liver in relation to the amount of liver excised. Cancer Res. 1964; 240:1611-1625. [PubMed: 14234005]

18. Stocker E, Pfeifer U. On the manner of proliferation of the liver parenchyma after partial hepatectomy. Autoradiography studies using 3H-thymidine. Naturwissenschaften. 1965; 52:663. [PubMed: 5873906]

19. Lindroos PM, Zarnegar R, Michalopoulos GK. Hepatocyte growth factor (hepatopoietin A) rapidly increases in plasma before DNA synthesis and liver regeneration stimulated by partial hepatectomy and carbon tetrachloride administration. Hepatology. 1991; 13:743-750. [PubMed: 1826282]

20. Short J, Klein K, Kibert L, et al. Involvement of the lodothyronines in liver and hepatoma cell proliferation in the rat. Cancer Res. 1980; 40:2417-2422. [PubMed: 7388800]

21. Cruise JL. Alpha 1-adrenergic receptors in liver regeneration. Dig Dis Sci. 1991; 36:485-488. [PubMed: 1848811]

22. Jirtle RL, Carr BI, Scott CD. Modulation of insulin-like growth factor-II/mannose 6-phosphate receptors and transforming growth factor-beta 1 during liver regeneration. J Biol Chem. 1991; 266:22444-22450. [PubMed: 1718994]

23. Huang W, Ma K, Zhang J, et al. Nuclear receptor-dependent bile acid signaling is required for normal liver regeneration. Science. 2006; 312:233-236. [PubMed: 16614213]

24. Dong J, Feldmann G, Huang J, et al. Elucidation of a universal size-control mechanism in Drosophila and mammals. Cell. 2007; 130:1120-1133. [PubMed: 17889654]

25. Shinozuka H, Lombardi B, Sell S, et al. Early histological and functional alterations of ethionine liver carcinogenesis in rats fed a choline-deficient diet. Cancer Res. 1978; 38:1092-1098. [PubMed: 76508]

26. Dorrell C, Erker L, Lanxon-Cookson KM, et al. Surface markers for the murine oval cell response. Hepatology. 2008; 48:1282-1291. [PubMed: 18726953]

27. Wang X, Foster M, Al-Dhalimy M, et al. The origin and liver repopulating capacity of murine oval cells. Proc Natl Acad Sci U S A. 2003; 100(Suppl 1):11881-11888. [PubMed: 12902545]

28. Alison MR, Golding M, Sarraf CE, et al. Liver damage in the rat induces hepatocyte stem cells from biliary epithelial cells. Gastroenterology. 1996; 110:1182-1190. [PubMed: 8613008]

29. Theise ND, Saxena R, Portmann BC, et al. The canals of Hering and hepatic stem cells in humans. Hepatology. 1999; 30:1425-1433. [PubMed: 10573521]

30. Jung Y, Brown KD, Witek RP, et al. Accumulation of hedgehog-responsive progenitors parallels alcoholic liver disease severity in mice and humans. Gastroenterology. 2008; 134:1532-1543. [PubMed: 18471524]

31. Yang S, Koteish A, Lin H, et al. Oval cells compensate for damage and replicative senescence of mature hepatocytes in mice with fatty liver disease. Hepatology. 2004; 39:403-411. [PubMed: 14767993]

32. Roskams T, Yang SQ, Koteish A, et al. Oxidative stress and oval cell accumulation in mice and humans with alcoholic and non-alcoholic fatty liver disease. Am J Pathol. 2003; 163:1301-1311. [PubMed: 14507639]

33. Spagnoli FM, Amicone L, Tripodi M, et al. Identification of a bipotential precursor cell in hepatic cell lines derived from transgenic mice expressing cyto-Met in the liver. J Cell Biol. 1998; 143:1101-1112. [PubMed: 9817765]

34. Strick-Marchand H, Morosan S, Charneau P, et al. Bipotential mouse embryonic liver stem cell lines contribute to liver regeneration and differentiate as bile ducts and hepatocytes. Proc Natl Acad Sci U S A. 2004; 101:8360-8365. [PubMed: 15155906] 
35. Sackett SD, Li Z, Hurtt R, et al. Foxl1 is a marker of bipotential hepatic progenitor cells in mice. Hepatology. 2009; 49:920-929. [PubMed: 19105206]

36. Preisegger KH, Factor VM, Fuchsbichler A, et al. Atypical ductular proliferation and its inhibition by transforming growth factor beta1 in the 3,5-diethoxycarbonyl-1,4-dihydrocollidine mouse model for chronic alcoholic liver disease. Lab Invest. 1999; 79:103-109. [PubMed: 10068199]

37. Faktor VM, Engel'gardt NV, Iazova AK, et al. Common antigens of oval cells and cholangiocytes in the mouse. Their detection by using monoclonal antibodies. Ontogenez. 1990; 21:625-632. [PubMed: 2095484]

38. Sanchez A, Factor VM, Schroeder IS, et al. Activation of NF-kappaB and STAT3 in rat oval cells during 2-acetylaminofluorene/partial hepatectomy-induced liver regeneration. Hepatology. 2004; 39:376-385. [PubMed: 14767990]

39. Fujio K, Evarts RP, Hu Z, et al. Expression of stem cell factor and its receptor, c-kit, during liver regeneration from putative stem cells in adult rat. Lab Invest. 1994; 70:511-516. [PubMed: 7513770]

40. Petersen BE, Goff JP, Greenberger JS, et al. Hepatic oval cells express the hematopoietic stem cell marker Thy-1 in the rat. Hepatology. 1998; 27:433-445. [PubMed: 9462642]

41. Spangrude GJ, Heimfeld S, Weissman IL. Purification and characterization of mouse hematopoietic stem cells. Science. 1988; 241:58-62. [PubMed: 2898810]

42. Dezso K, Jelnes P, Laszlo V, et al. Thy-1 is expressed in hepatic myofibroblasts and not oval cells in stem cell-mediated liver regeneration. Am J Pathol. 2007; 171:1529-1537. [PubMed: 17884967]

43. Baumann U, Crosby HA, Ramani P, et al. Expression of the stem cell factor receptor c-kit in normal and diseased pediatric liver: identification of a human hepatic progenitor cell? Hepatology. 1999; 30:112-117. [PubMed: 10385646]

44. Petersen BE, Grossbard B, Hatch H, et al. Mouse A6-positive hepatic oval cells also express several hematopoietic stem cell markers. Hepatology. 2003; 37:632-640. [PubMed: 12601361]

45. Erker L, Grompe M. Signaling networks in hepatic oval cell activation. Stem Cell Res. 2008; 1:90102. [PubMed: 19383389]

46. Sun R, Gao B. Negative regulation of liver regeneration by innate immunity (natural killer cells/ interferon-gamma). Gastroenterology. 2004; 127:1525-1539. [PubMed: 15521020]

47. Akhurst B, Matthews V, Husk K, et al. Differential lymphotoxin-beta and interferon gamma signaling during mouse liver regeneration induced by chronic and acute injury. Hepatology. 2005; 41:327-335. [PubMed: 15660390]

48. Brooling JT, Campbell JS, Mitchell C, et al. Differential regulation of rodent hepatocyte and oval cell proliferation by interferon gamma. Hepatology. 2005; 41:906-915. [PubMed: 15799032]

49. Matthews VB, Klinken E, Yeoh GC. Direct effects of interleukin-6 on liver progenitor oval cells in culture. Wound Repair Regen. 2004; 12:650-656. [PubMed: 15555057]

50. Knight B, Yeoh GC, Husk KL, et al. Impaired preneoplastic changes and liver tumor formation in tumor necrosis factor receptor type 1 knockout mice. J Exp Med. 2000; 192:1809-1818. [PubMed: 11120777]

51. Jakubowski A, Ambrose C, Parr M, et al. TWEAK induces liver progenitor cell proliferation. J Clin Invest. 2005; 115:2330-2340. [PubMed: 16110324]

52. Fleig SV, Choi SS, Yang L, et al. Hepatic accumulation of Hedgehog-reactive progenitors increases with severity of fatty liver damage in mice. Lab Invest. 2007; 87:1227-1239. [PubMed: 17952094]

53. Sell S, Dunsford HA. Evidence for the stem cell origin of hepatocellular carcinoma and cholangiocarcinoma. Am J Pathol. 1989; 134:1347-1363. [PubMed: 2474256]

54. Sell S, Leffert HL. An evaluation of cellular lineages in the pathogenesis of experimental hepatocellular carcinoma. Hepatology. 1982; 2:77-86. [PubMed: 6172353]

55. Braun L, Mikumo R, Fausto N. Production of hepatocellular carcinoma by oval cells: cell cycle expression of c-myc and p53 at different stages of oval cell transformation. Cancer Res. 1989; 49:1554-1561. [PubMed: 2647288]

56. Yaswen P, Goyette M, Shank PR, et al. Expression of c-Ki-ras, c-Ha-ras, and c-myc in specific cell types during hepatocarcinogenesis. Mol Cell Biol. 1985; 5:780-786. [PubMed: 2581126] 
57. Libbrecht L, Roskams T. Hepatic progenitor cells in human liver diseases. Semin Cell Dev Biol. 2002; 13:389-396. [PubMed: 12468238]

58. Wu PC, Fang JW, Lau VK, et al. Classification of hepatocellular carcinoma according to hepatocellular and biliary differentiation markers. Clinical and biological implications. Am J Pathol. 1996; 149:1167-1175. [PubMed: 8863666]

59. Komuta M, Spee B, Borght S Vander, et al. Clinicopathological study on cholangiocellular carcinoma suggesting hepatic progenitor cell origin. Hepatology. 2008; 47:1544-1556. [PubMed: 18393293]

60. Kobayashi N, Fujiwara T, Westerman KA, et al. Prevention of acute liver failure in rats with reversibly immortalized human hepatocytes. Science. 2000; 287:1258-1262. [PubMed: 10678831]

61. Kobayashi N, Ito M, Nakamura J, et al. Hepatocyte transplantation in rats with decompensated cirrhosis. Hepatology. 2000; 31:851-857. [PubMed: 10733539]

62. Kobayashi N, Miyazaki M, Fukaya K, et al. Establishment of a highly differentiated immortalized human hepatocyte cell line as a source of hepatic function in the bioartificial liver. Transplant Proc. 2000; 32:237-241. [PubMed: 10715403]

63. Gupta, S.; Chowdhury, JR. Hepatocyte transplantation. In: Arias, IM., editor. The liver-biology and pathobiology. 3rd ed. Raven; New York, NY: 1994. p. 1519-1536.

64. Fox IJ, Chowdhury NR, Gupta S, et al. Conditional immortalization of Gunn rat hepatocytes: an ex vivo model for evaluating methods for bilirubin-UDP-glucuronosyltransferase gene transfer. Hepatology. 1995; 21:837-846. [PubMed: 7875682]

65. Suzuki A, Zheng YW, et al. Clonal identification and characterization of self-renewing pluripotent stem cells in the developing liver. J Cell Biol. 2002; 156:173-184. [PubMed: 11781341]

66. Suzuki A, Sekiya S, Onishi M, et al. Flow cytometric isolation and clonal identification of selfrenewing bipotent hepatic progenitor cells in adult mouse liver. Hepatology. 2008; 48:1964-1978. [PubMed: 18837044]

67. Schmelzer E, Zhang L, Bruce A, et al. Human hepatic stem cells from fetal and postnatal donors. J Exp Med. 2007; 204:1973-1987. [PubMed: 17664288]

68. Suzuki, A.; Oyama, K.; Fukao, K., et al. Prospective isolation and enrichment of pancreatic stem/ progenitor cells. Conference on Pancreatic Development, Proliferation and Stem Cells; Bethesda, MD. National Institutes of Health; 2001.

69. Zhang L, Theise N, Chua M, et al. The stem cell niche of human livers: symmetry between development and regeneration. Hepatology. 2008; 48:1598-1607. [PubMed: 18972441]

70. Jiang Y, Jahagirdar BN, Reinhardt RL, et al. Pluripotency of mesenchymal stem cells derived from adult marrow. Nature. 2002; 418:41-49. [PubMed: 12077603]

71. Reyes M, Verfaillie CM. Characterization of multipotent adult progenitor cells, a subpopulation of mesenchymal stem cells. Ann N Y Acad Sci. 2001; 938:231-233. discussion 233-235. [PubMed: 11458512]

72. Schwartz RE, Reyes M, Koodie L, et al. Multipotent adult progenitor cells from bone marrow differentiate into functional hepatocyte-like cells. J Clin Invest. 2002; 109:1291-1302. [PubMed: 12021244]

73. Grompe M. Adult versus embryonic stem cells: it's still a tie. Mol Ther. 2002; 6:303-305. [PubMed: 12231164]

74. Aurich H, Sgodda M, Kaltwasser P, et al. Hepatocyte differentiation of mesenchymal stem cells from human adipose tissue in vitro promotes hepatic integration in vivo. Gut. 2009; 58:570-581. [PubMed: 19022918]

75. Aurich I, Mueller LP, Aurich H, et al. Functional integration of hepatocytes derived from human mesenchymal stem cells into mouse livers. Gut. 2007; 56:405-415. [PubMed: 16928726]

76. Banas A, Teratani T, Yamamoto Y, et al. Adipose tissue-derived mesenchymal stem cells as a source of human hepatocytes. Hepatology. 2007; 46:219-228. [PubMed: 17596885]

77. Miki T, Lehmann T, Cai H, et al. Stem cell characteristics of amniotic epithelial cells. Stem Cells. 2005; 23:1549-1559. [PubMed: 16081662]

78. De Coppi P, Bartsch G Jr, Siddiqui MM, et al. Isolation of amniotic stem cell lines with potential for therapy. Nat Biotechnol. 2007; 25:100-106. [PubMed: 17206138] 
79. Miki T, Marongiu F, Ellis EC, et al. Production of hepatocyte-like cells from human amnion. Methods Mol Biol. 2009; 481:1-14. [PubMed: 19096807]

80. Asahina K, Teramoto K, Teraoka H. Embryonic stem cells: hepatic differentiation and regenerative medicine for the treatment of liver disease. Curr Stem Cell Res Ther. 2006; 1:139-156. [PubMed: 18220863]

81. Gouon-Evans V, Boussemart L, Gadue P, et al. BMP-4 is required for hepatic specification of mouse embryonic stem cell-derived definitive endoderm. Nat Biotechnol. 2006; 24:1402-1411. [PubMed: 17086172]

82. Heo J, Factor VM, Uren T, et al. Hepatic precursors derived from murine embryonic stem cells contribute to regeneration of injured liver. Hepatology. 2006; 44:1478-1486. [PubMed: 17133486]

83. Hay DC, Fletcher J, Payne C, et al. Highly efficient differentiation of hESCs to functional hepatic endoderm requires ActivinA and Wnt3a signaling. Proc Natl Acad Sci U S A. 2008; 105:1230112306. [PubMed: 18719101]

84. Basma H, Soto-Gutierrez A, Yannam GR, et al. Differentiation and transplantation of human embryonic stem cell-derived hepatocytes. Gastroenterology. 2009; 136:767-769. [PubMed: 19167399]

85. Takahashi K, Yamanaka S. Induction of pluripotent stem cells from mouse embryonic and adult fibroblast cultures by defined factors. Cell. 2006; 126:663-676. [PubMed: 16904174]

86. Coleman WB, Wennerberg AE, Smith GJ, et al. Regulation of the differentiation of diploid and some aneuploid rat liver epithelial (stemlike) cells by the hepatic microenvironment. Am J Pathol. 1993; 142:1373-1382. [PubMed: 8494041]

87. Coleman WB, McCullough KD, Esch GL, et al. Evaluation of the differentiation potential of WBF344 rat liver epithelial stem-like cells in vivo. Differentiation to hepatocytes after transplantation into dipeptidylpeptidase-IV-deficient rat liver. Am J Pathol. 1997; 151:353-359. [PubMed: 9250149]

88. Dees C, Travis C. Phenotypic and genotypic analysis of rat liver epithelial cells infected with retroviral shuttle vectors. Cancer Lett. 1996; 107:19-28. [PubMed: 8913262]

89. Grisham JW, Coleman WB. Neoformation of liver epithelial cells: progenitor cells, stem cells, and phenotypic transitions. Gastroenterology. 1996; 110:1311-1313. [PubMed: 8613023]

90. Amicone L, Spagnoli FM, Spath G, et al. Transgenic expression in the liver of truncated Met blocks apoptosis and permits immortalization of hepatocytes. EMBO J. 1997; 16:495-503. [PubMed: 9034332]

91. Rogler LE. Selective bipotential differentiation of mouse embryonic hepatoblasts in vitro. Am J Pathol. 1997; 150:591-602. [PubMed: 9033273]

92. Ott M, Ma Q, Li B, et al. Regulation of hepatitis B virus expression in progenitor and differentiated cell types: evidence for negative transcriptional control in nonpermissive cells. Gene Expr. 1999; 8:175-186. [PubMed: 10634319]

93. Ader T, Norel R, Levoci L, et al. Transcriptional profiling implicates TGFbeta/BMP and Notch signaling pathways in ductular differentiation of fetal murine hepatoblasts. Mech Dev. 2006; 123:177-194. [PubMed: 16412614]

94. Nussler AK, Vergani G, Gollin SM, et al. Isolation and characterization of a human hepatic epithelial-like cell line (AKN-1) from a normal liver. In Vitro Cell Dev Biol Anim. 1999; 35:190197. [PubMed: 10478798]

95. Talbot NC, Rexroad CE Jr, Pursel VG, et al. Culturing the epiblast cells of the pig blastocyst. In Vitro Cell Dev Biol Anim. 1993; 29A:534-554.

96. Grompe M. Pancreatic-hepatic switches in vivo. Mech Dev. 2003; 120:99-106. [PubMed: 12490300]

97. Bisgaard HC, Thorgeirsson SS. Evidence for a common cell of origin for primitive epithelial cells isolated from rat liver and pancreas. J Cell Physiol. 1991; 147:333-343. [PubMed: 1710229]

98. Chen JR, Tsao MS, Duguid WP. Hepatocytic differentiation of cultured rat pancreatic ductal epithelial cells after in vivo implantation. Am J Pathol. 1995; 147:707-717. [PubMed: 7677182]

99. Yamanouchi K, Zhou H, Roy-Chowdhury N, et al. Hepatic irradiation augments engraftment of donor cells following hepatocyte transplantation. Hepatology. 2009; 49:258-267. [PubMed: 19003915] 
100. Meuleman P, Libbrecht L, De Vos R, et al. Morphological and biochemical characterization of a human liver in a uPA-SCID mouse chimera. Hepatology. 2005; 41:847-856. [PubMed: 15791625]

101. Dandri M, Burda MR, Torok E, et al. Repopulation of mouse liver with human hepatocytes and in vivo infection with hepatitis B virus. Hepatology. 2001; 33:981-988. [PubMed: 11283864]

102. Azuma H, Paulk N, Ranade A, et al. Robust expansion of human hepatocytes in Fah-/-/Rag2-/ -/I12rg-/- mice. Nat Biotechnol. 2007; 25:903-910. [PubMed: 17664939]

103. Igarashi Y, Tateno C, Tanaka Y, et al. Engraftment of human hepatocytes in the livers of rats bearing bone marrow reconstructed with immunodeficient mouse bone marrow cells. Xenotransplantation. 2008; 15:235-245. [PubMed: 18957046]

104. Overturf K, Al-Dhalimy M, Ou CN, et al. Serial transplantation reveals the stem-cell-like regenerative potential of adult mouse hepatocytes. Am J Pathol. 1997; 151:1273-1280. [PubMed: 9358753]

105. Overturf K, Al-Dhalimy M, Finegold M, et al. The repopulation potential of hepatocyte populations differing in size and prior mitotic expansion. Am J Pathol. 1999; 155:2135-2143. [PubMed: 10595942]

106. Wang X, Willenbring H, Akkari Y, et al. Cell fusion is the principal source of bone-marrowderived hepatocytes. Nature. 2003; 422:897-901. [PubMed: 12665832]

107. Weglarz TC, Degen JL, Sandgren EP. Hepatocyte transplantation into diseased mouse liver. Kinetics of parenchymal repopulation and identification of the proliferative capacity of tetraploid and octaploid hepatocytes. Am J Pathol. 2000; 157:1963-1974. [PubMed: 11106569]

108. Kvittingen EA, Rootwelt H, Berger R, et al. Self-induced correction of the genetic defect in tyrosinemia type I. J Clin Invest. 1994; 94:1657-1661. [PubMed: 7929843]

109. Limaye PB, Bowen WC, Orr AV, et al. Mechanisms of hepatocyte growth factor-mediated and epidermal growth factor-mediated signaling in transdifferentiation of rat hepatocytes to biliary epithelium. Hepatology. 2008; 47:1702-1713. [PubMed: 18398918]

110. Dabeva MD, Petkov PM, Sandhu J, et al. Proliferation and differentiation of fetal liver epithelial progenitor cells after transplantation into adult rat liver. Am J Pathol. 2000; 156:2017-2031. [PubMed: 10854224]

111. Mahieu-Caputo D, Allain JE, Branger J, et al. Repopulation of athymic mouse liver by cryopreserved early human fetal hepatoblasts. Hum Gene Ther. 2004; 15:1219-1228. [PubMed: 15684698]

112. Nierhoff D, Ogawa A, Oertel M, et al. Purification and characterization of mouse fetal liver epithelial cells with high in vivo repopulation capacity. Hepatology. 2005; 42:130-139. [PubMed: 15895427]

113. Oertel M, Menthena A, Chen YQ, et al. Purification of fetal liver stem/progenitor cells containing all the repopulation potential for normal adult rat liver. Gastroenterology. 2008; 134:823-832. [PubMed: 18262526]

114. Dabeva MD, Hwang SG, Vasa SR, et al. Differentiation of pancreatic epithelial progenitor cells into hepatocytes following transplantation into rat liver. Proc Natl Acad Sci U S A. 1997; 94:7356-7361. [PubMed: 9207095]

115. Spooner BS, Walther BT, Rutter WJ. The development of the dorsal and ventral mammalian pancreas in vivo and in vitro. J Cell Biol. 1970; 47:235-246. [PubMed: 5513553]

116. Rutter WJ. The development of the endocrine and exocrine pancreas. Monogr Pathol. 1980; 21:30-38. [PubMed: 7012591]

117. Gerber, MA.; Thung, SN. Cell lineages in human liver development, regeneration and transplantation. In: Sirica, AE., editor. The role of cell types in hepatocarcinogenesis. CRC Press; Boca Raton, FL: 1992. p. 209-226.

118. Shiojiri N, Lemire JM, Fausto N. Cell lineages and oval cell progenitors in rat liver development. Cancer Res. 1991; 51:2611-2620. [PubMed: 1708696]

119. Scarpelli DG, Rao MS. Differentiation of regenerating pancreatic cells into hepatocyte-like cells. Proc Natl Acad Sci U S A. 1981; 78:2577-2581. [PubMed: 6941311]

120. Lalwani ND, Reddy MK, Qureshi SA, et al. Development of hepatocellular carcinomas and increased peroxisomal fatty acid beta-oxidation in rats fed [4-chloro-6-(2,3-xylidino)-2- 
pyrimidinylthio] acetic acid (Wy-14,643) in the semipurified diet. Carcinogenesis. 1981; 2:645650. [PubMed: 7273344]

121. Rao MS, Subbarao V, Reddy JK. Induction of hepatocytes in the pancreas of copper-depleted rats following copper repletion. Cell Differ. 1986; 18:109-117. [PubMed: 3513967]

122. Krakowski ML, Kritzik MR, Jones EM, et al. Pancreatic expression of keratinocyte growth factor leads to differentiation of islet hepatocytes and proliferation of duct cells. Am J Pathol. 1999; 154:683-691. [PubMed: 10079246]

123. Hruban RH, Molina JM, Reddy MN, et al. A neoplasm with pancreatic and hepatocellular differentiation presenting with subcutaneous fat necrosis. Am J Clin Pathol. 1987; 88:639-645. [PubMed: 3673946]

124. Wang X, Al-Dhalimy M, Lagasse E, et al. Liver repopulation and correction of metabolic liver disease by transplanted adult mouse pancreatic cells. Am J Pathol. 2001; 158:571-579. [PubMed: 11159194]

125. Terada T, Nakanuma Y. An immunohistochemical survey of amylase isoenzymes in cholangiocarcinoma and hepatocellular carcinoma. Arch Pathol Lab Med. 1993; 117:160-162. [PubMed: 8381270]

126. Yin, L.; Arenas, MS.; Clark, A., et al. The potentiality of liver oval cells to differentiate into insulin-producing cells. Conference on Pancreatic Development, Proliferation and Stem Cells; Bethesda, MD. National Institutes of Health; 2001.

127. Kojima H, Fujimiya M, Matsumura K, et al. NeuroD-betacellulin gene therapy induces islet neogenesis in the liver and reverses diabetes in mice. Nat Med. 2003; 9:596-603. [PubMed: 12704384]

128. Sapir T, Shternhall K, Meivar-Levy I, et al. Cell-replacement therapy for diabetes: Generating functional insulin-producing tissue from adult human liver cells. Proc Natl Acad Sci U S A. 2005; 102:7964-7969. [PubMed: 15899968]

129. Yan Y, Xu W, Qian H, et al. Mesenchymal stem cells from human umbilical cords ameliorate mouse hepatic injury in vivo. Liver Int. 2009; 29:356-365. [PubMed: 19141029]

130. Banas A, Teratani T, Yamamoto Y, et al. IFATS collection: in vivo therapeutic potential of human adipose tissue mesenchymal stem cells after transplantation into mice with liver injury. Stem Cells. 2008; 26:2705-2712. [PubMed: 18535155]

131. Kuo TK, Hung SP, Chuang CH, et al. Stem cell therapy for liver disease: parameters governing the success of using bone marrow mesenchymal stem cells. Gastroenterology. 2008; 134:21112121. 2121.e1-3. [PubMed: 18455168]

132. Aziz, MT Abdel; Atta, HM.; Mahfouz, S., et al. Therapeutic potential of bone marrow-derived mesenchymal stem cells on experimental liver fibrosis. Clin Biochem. 2007; 40:893-899. [PubMed: 17543295]

133. Banas A, Teratani T, Yamamoto Y, et al. Rapid hepatic fate specification of adipose-derived stem cells and their therapeutic potential for liver failure. J Gastroenterol Hepatol. 2009; 24:70-77. [PubMed: 18624899]

134. Carvalho AB, Quintanilha LF, Dias JV, et al. Bone marrow multipotent mesenchymal stromal cells do not reduce fibrosis or improve function in a rat model of severe chronic liver injury. Stem Cells. 2008; 26:1307-1314. [PubMed: 18308943]

135. Russo FP, Alison MR, Bigger BW, et al. The bone marrow functionally contributes to liver fibrosis. Gastroenterology. 2006; 130:1807-1821. [PubMed: 16697743]

136. di Bonzo LV, Ferrero I, Cravanzola C, et al. Human mesenchymal stem cells as a two-edged sword in hepatic regenerative medicine: engraftment and hepatocyte differentiation versus profibrogenic potential. Gut. 2008; 57:223-231. [PubMed: 17639088]

137. Parekkadan B, van Poll D, Suganuma K, et al. Mesenchymal stem cell-derived molecules reverse fulminant hepatic failure. PLoS ONE. 2007; 2:e941. [PubMed: 17895982]

138. van Poll D, Parekkadan B, Cho CH, et al. Mesenchymal stem cell-derived molecules directly modulate hepatocellular death and regeneration in vitro and in vivo. Hepatology. 2008; 47:16341643. [PubMed: 18395843]

139. Petersen BE, Bowen WC, Patrene KD, et al. Bone marrow as a potential source of hepatic oval cells. Science. 1999; 284:1168-1170. [PubMed: 10325227] 
140. Theise ND, Badve S, Saxena R, et al. Derivation of hepatocytes from bone marrow cells in mice after radiation-induced myeloablation. Hepatology. 2000; 31:235-240. [PubMed: 10613752]

141. Alison MR, Poulsom R, Jeffery R, et al. Hepatocytes from non-hepatic adult stem cells. Nature. 2000; 406:257. [PubMed: 10917519]

142. Theise ND, Nimmakayalu M, Gardner R, et al. Liver from bone marrow in humans. Hepatology. 2000; 32:11-16. [PubMed: 10869283]

143. Lagasse E, Connors H, Al-Dhalimy M, et al. Purified hematopoietic stem cells can differentiate into hepatocytes in vivo. Nat Med. 2000; 6:1229-1234. [PubMed: 11062533]

144. Danet GH, Luongo JL, Butler G, et al. C1qRp defines a new human stem cell population with hematopoietic and hepatic potential. Proc Natl Acad Sci U S A. 2002; 99:10441-10445. [PubMed: 12140365]

145. Wang X, Ge S, McNamara G, et al. Albumin expressing hepatocyte-like cells develop in the livers of immune-deficient mice transmitted with highly purified human hematopoietic stem cells. Blood. 2003; 101:4201-4208. [PubMed: 12560238]

146. Duncan AW, Hickey RD, Paulk NK, et al. Ploidy reductions in murine fusion-derived hepatocytes. PLoS Genet. 2009; 5:e1000385. [PubMed: 19229314]

147. Vassilopoulos G, Wang PR, Russell DW. Transplanted bone marrow regenerates liver by cell fusion. Nature. 2003; 422:901-904. [PubMed: 12665833]

148. Willenbring H, Bailey AS, Foster M, et al. Myelomonocytic cells are sufficient for therapeutic cell fusion in liver. Nat Med. 2004; 10:744-748. [PubMed: 15195088]

149. Wagers AJ, Sherwood RI, Christensen JL, et al. Little evidence for developmental plasticity of adult hematopoietic stem cells. Science. 2002; 297:2256-2259. [PubMed: 12215650]

150. Wang X, Montini E, Al-Dhalimy M, et al. Kinetics of liver repopulation after bone marrow transplantation. Am J Pathol. 2002; 161:565-574. [PubMed: 12163381]

151. Factor VM, Radaeva SA, Thorgeirsson SS. Origin and fate of oval cells in dipin-induced hepatocarcinogenesis in the mouse. Am J Pathol. 1994; 145:409-422. [PubMed: 8053498]

152. Rosenberg D, Ilic Z, Yin L, et al. Proliferation of hepatic lineage cells of normal C57BL and interleukin-6 knockout mice after cocaine-induced periportal injury. Hepatology. 2000; 31:948955. [PubMed: 10733552]

153. Teebor GW, Becker FF. Regression and persistence of hyperplastic hepatic nodules induced by N-2-fluorenylacetamide and their relationship to hepatocarcinogenesis. Cancer Res. 1971; 31:13. [PubMed: 5540951]

154. Schwarze PE, Pettersen EO, Shoaib MC, et al. Emergence of a population of small, diploid hepatocytes during hepatocarcinogenesis. Carcinogenesis. 1984; 5:1267-1275. [PubMed: 6149024]

155. Solt DB, Medline A, Farber E. Rapid emergence of carcinogen-induced hyperplastic lesions in a new model for the sequential analysis of liver carcinogenesis. Am J Pathol. 1977; 88:595-618. [PubMed: 18937]

156. Evarts RP, Nakatsukasa H, Marsden ER, et al. Cellular and molecular changes in the early stages of chemical hepatocarcinogenesis in the rat. Cancer Res. 1990; 50:3439-3444. [PubMed: 1692260]

157. Lemire JM, Shiojiri N, Fausto N. Oval cell proliferation and the origin of small hepatocytes in liver injury induced by D-galactosamine. Am J Pathol. 1991; 139:535-552. [PubMed: 1716045]

158. Laconi E, Sarma DS, Pani P. Transplantation of normal hepatocytes modulates the development of chronic liver lesions induced by a pyrrolizidine alkaloid, lasiocarpine. Carcinogenesis. 1995; 16:139-142. [PubMed: 7834799]

159. Laconi E, Oren R, Mukhopadhyay DK, et al. Long-term, near-total liver replacement by transplantation of isolated hepatocytes in rats treated with retrorsine. Am J Pathol. 1998; 153:319-329. [PubMed: 9665494]

160. Gordon GJ, Coleman WB, Hixson DC, et al. Liver regeneration in rats with retrorsine-induced hepatocellular injury proceeds through a novel cellular response. Am J Pathol. 2000; 156:607619. [PubMed: 10666390]

161. Rhim JA, Sandgren EP, Degen JL, et al. Replacement of diseased mouse liver by hepatic cell transplantation. Science. 1994; 263:1149-1152. [PubMed: 8108734] 
162. Overturf K, Al-Dhalimy M, Tanguay R, et al. Hepatocytes corrected by gene therapy are selected in vivo in a murine model of hereditary tyrosinaemia type I. Nat Genet. 1996; 12:266-273. [PubMed: 8589717]

163. Braun KM, Degen JL, Sandgren EP. Hepatocyte transplantation in a model of toxin-induced liver disease: variable therapeutic effect during replacement of damaged parenchyma by donor cells. Nat Med. 2000; 6:320-326. [PubMed: 10700235]

164. De Vree JM, Ottenhoff R, Bosma PJ, et al. Correction of liver disease by hepatocyte transplantation in a mouse model of progressive familial intrahepatic cholestasis. Gastroenterology. 2000; 119:1720-1730. [PubMed: 11113093]

165. Mignon A, Guidotti JE, Mitchell C, et al. Selective repopulation of normal mouse liver by Fas/ CD95-resistant hepatocytes. Nat Med. 1998; 4:1185-1188. [PubMed: 9771754]

166. Guo D, Fu T, Nelson JA, et al. Liver repopulation after cell transplantation in mice treated with retrorsine and carbon tetrachloride. Transplantation. 2002; 73:1818-1824. [PubMed: 12085007]

167. Guha C, Sharma A, Gupta S, et al. Amelioration of radiation-induced liver damage in partially hepatectomized rats by hepatocyte transplantation. Cancer Res. 1999; 59:5871-5874. [PubMed: 10606225]

168. Dorrell, C.; Grompe, M. Adult liver stem cells. Elsevier; New York, NY: 2006. 


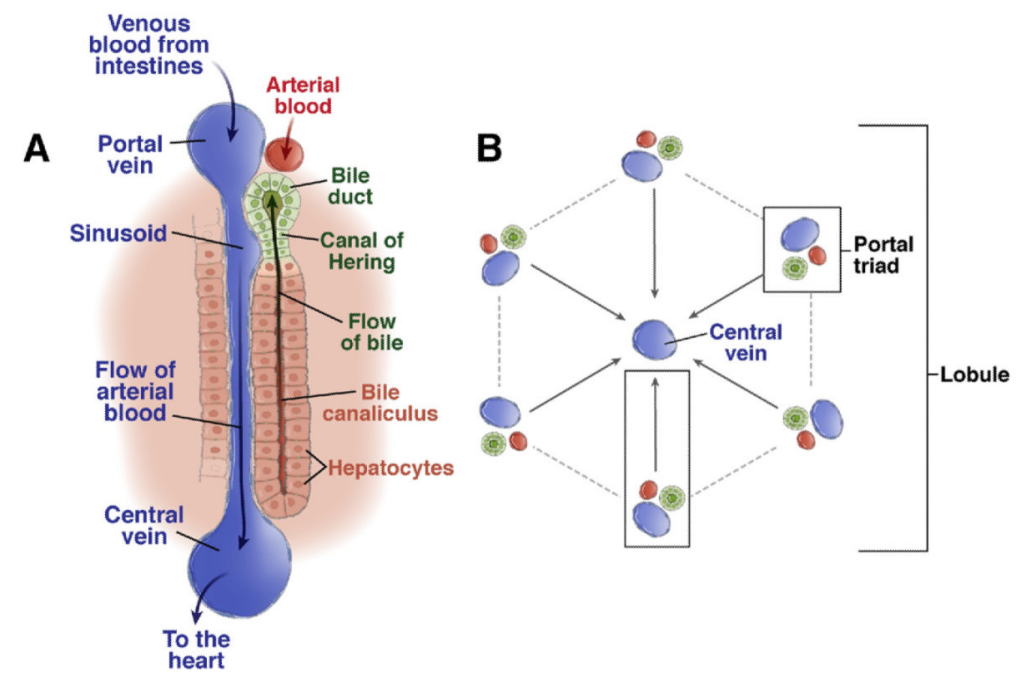

Figure 1.

Structure of the hepatic lobule. $(A)$ The portal triad consists of bile ducts, hepatic artery, and portal vein. ${ }^{168}$ Mixed blood from the hepatic artery and portal vein flows past hepatocytes through the sinusoids, covered with fenestrated endothelial cells to the central vein. Bile produced by the hepatocytes is collected in the bile canaliculus and flows towards the bile duct. The Canal of Hering is the junction between the hepatic plate and the bile ducts. This is the region where oval cell precursors reside. $(B)$ Each hepatic lobule consists of 1 central vein and 6 surrounding portal triads. 


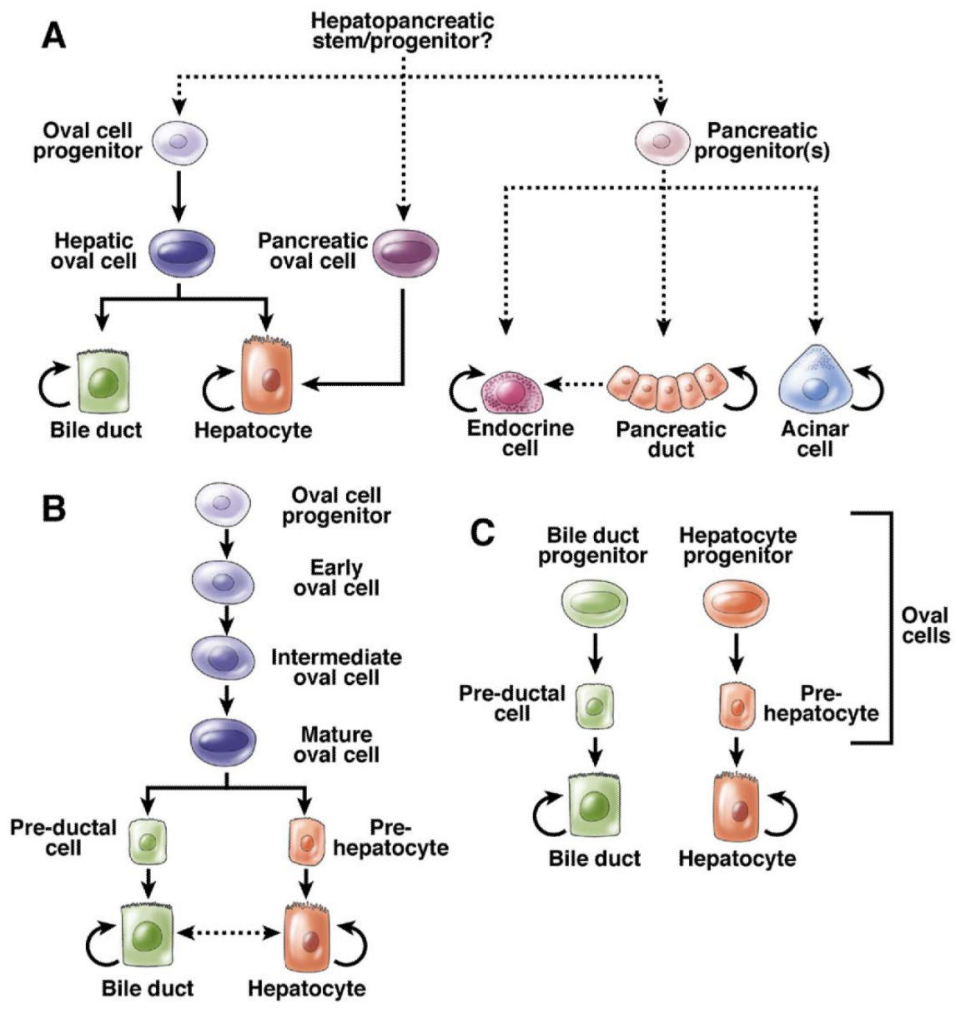

Figure 2.

Progenitor lineage relationships in adult liver and pancreas. (A) Classic model depicting one single hepatic oval cell type, which is the immediate off-spring of the intrahepatic oval cell progenitor and immediate precursor to both hepatocytes and bile ducts. Dashed lines delineate rare or hypothetical cell fate transitions that occur only under specific experimental conditions. (B) Oval cell heterogeneity model. Different stages of oval cell maturation exist, differing in proliferative potential as well as gene expression. The most mature oval cell is bipotential and gives rise to pre-hepatocytes and pre-ductal cells, which are not yet fully mature. $(C)$ Unilineage model. Distinct unilineage progenitor cells give rise to bile ducts or hepatocytes, possibly by differentiating through intermediate cell types. These progenitor cells could comprise the oval cell population. 


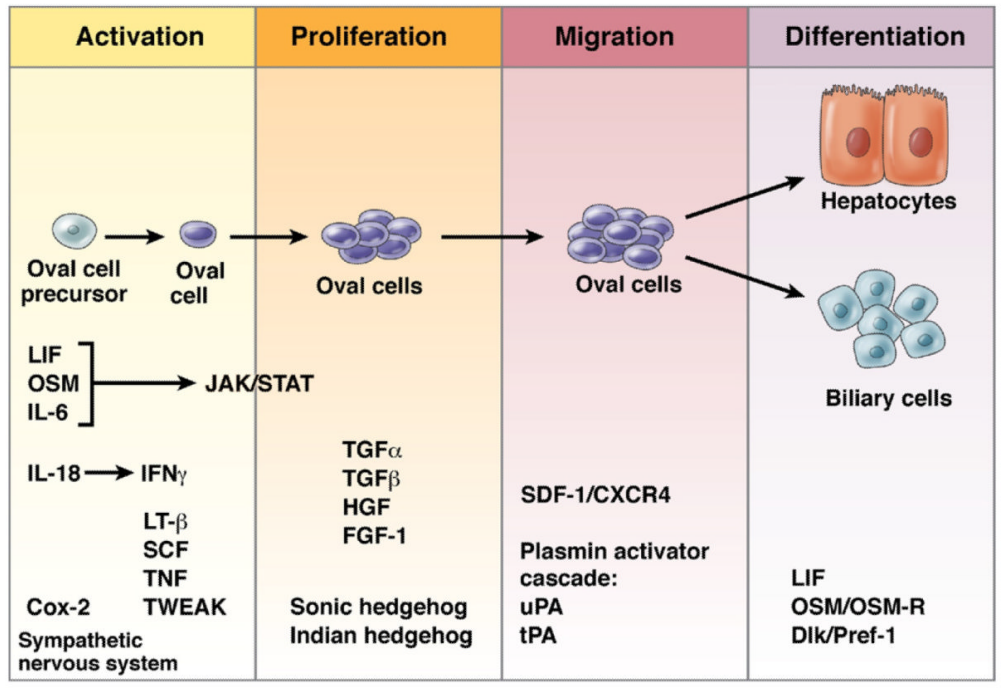

Figure 3.

Signaling events during the hepatic oval cell response. A time line representing the stages of oval cell activation ${ }^{45}$ : activation, proliferation, migration, and differentiation. The factors that are involved in each stage of the response are listed at the bottom. 

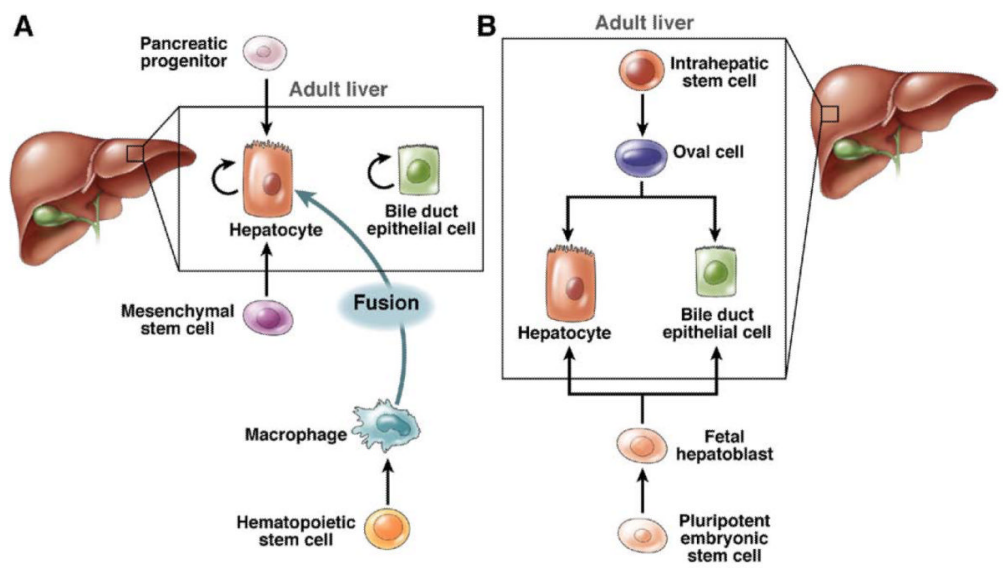

Figure 4.

Cells with adult liver-repopulating potential. (A) Unipotential liver-repopulating cells. Hepatocytes and bile duct epithelial cells regenerate during normal tissue turnover. Under defined experimental conditions, pancreatic progenitor cells and MSCs differentiate into hepatocytes, and HSC-derived myelomonocytic cells fuse with hepatocytes. (B) Bipotential liver-repopulating cells. Intrahepatic liver stem cells and/or oval cells differentiate into hepatocytes and bile duct epithelial cells (ie, oval cell response). Fetal hepatoblasts, derived from pluripotent ESCs, also differentiate into hepatocytes and bile duct epithelial cells in transplantation experiments. 
Table 1

Induction of Progenitor-Dependent Liver Regeneration

\begin{tabular}{ll}
\hline Chemical/manipulation & Reference \\
\hline Mouse & 151 \\
Dipin & 36 \\
DDC & 152 \\
Phenobarbital + cocaine + PH & 50 \\
Choline-deficient diet + DL-ethionine & 30 \\
High-fat diet + ethanol & \\
Rat & 153 \\
AAF & 154 \\
Diethylnitrosamine & 155 \\
Solt-Farber model: diethylnitrosamine + & \\
$\quad$ AAF + PH & 156 \\
Modified Solt-Farber model: AAF + PH & 25 \\
Choline-deficient diet + DL-ethionine & 157 \\
D-galactosamine + PH & 158 \\
Lasiocarpine + PH & 159,160 \\
Retrorsine + PH & 156 \\
\hline
\end{tabular}

AAF, 2-acetylaminofluorene; PH, partial hepatectomy. 
